\title{
Morphological and productivity comparison between commercial and wild isolates of Pleurotus eryngii (D.C.: Fr.) Quél
}

\author{
Donato Castronuovo, Stefania M. Mang, Antonella Becce, Vincenzo Candido, \\ Loriana Cardone, Ippolito Camele \\ School of Agriculture, Forestry and Environmental Sciences, University of Basilicata, Potenza, Italy
}

\begin{abstract}
Seven commercial isolates of Pleurotus eryngii ('142 F', '142 E', 'D +', 'V turbo', 'V 142', 'A12' and 'V160'), identified on molecular basis, were compared to five wild type isolates ('Albino beige chiaro 1094', 'Altamura 1603', 'Albino 1107', 'Muro Lucano 139' and 'Conversano 1250') concerning their morphological, productivity and quality features. Interestingly, two wild type isolates ('Albino 1107' and 'Conversano 1250') resulted more productive then all the commercial fungal isolates analysed. Besides, all wild isolates of $P$. eryngii showed harvest earliness and among them 'Altamura 1603' and 'Conversano 1250' were the best. The highest percentage of large basidioma was observed for the commercial isolates ' $\mathrm{V}$ turbo' and ' $\mathrm{D}+$ '. Within the wild types, the isolate 'Conversano 1250' stood out. Regarding the pileus cuticle colour, commercial isolates ('V turbo' and 'V 160') showed lower lightness value than wild type isolates ('Albino $\left.1107^{\prime}\right)$.
\end{abstract}

\section{Introduction}

Mushrooms are foods with high nutritional value and health benefits thanks to their low caloric intake, fat content and a good supply of minerals and vitamins along with antitumoral properties (Coli et al., 1988; Jong and Donovich, 1989; Hobbs, 1995; Chang et al., 1996; Manzi et al., 1999; Guzmàn, 2000; Muszyńska et al., 2017). For this reasons, many studies were undertaken to recognise edible fungi, investigate the quality features, improve the production techniques, clarify their taxonomy and diseases (Ferri, 1986; Zervakis and Balis, 1996; Sisto et al., 1998; Ferri, 2000; Maddau et al., 2000; De Gioia et al., 2007; Ferri et al., 2007; Camele et al., 2010; Mang and Figliuolo, 2010; Rodriguez Estrada et al., 2010; Kim et al., 2013; Zhang et al., 2014; Zervakis et al., 2014; Venturella et al., 2015; Gorai and Sharma, 2018).

As edible fungi, Pleurotus eryngii (D.C.: Fr.) Quél. is undoubtedly one of the most known and cultivated mushroom from the past. It is also very much appreciated throughout all Italy, and in the Southern region it is commonly referred as cardoncello. In the last decades, the cultivation of this fungus has assumed an ever-increasing expansion and diffusion worldwide (Ferri, 1986; Zhang et al., 2014; Ryu et al., 2015). Furthermore, for P. eryngii various beneficial effects on human health have been demonstrated thanks to the hypocholesterolemic and hypoglycaemic properties and several studies have confirmed their antioxidant, immunomodulatory, antiosteoporotic and antitumor properties (Jong and Donovich, 1989; Grunde-Cimerman, 1999; Guzmàn, 2000; Wang and Ng, 2001; Ngai and Ng, 2006; Muszyńska et al., 2017).

Our studies were directed to discover new promising P. eryngii isolates with better marketable features compared with the already commercially available ones. For this purpose, seven commercial and five wild $P$. eryngii isolates, identified at species level based on molecular basis, were evaluated for their morphological, productivity and some quality characteristics.

\section{Materials and methods}

\section{Fungal isolation, inoculation and culture}

The isolates of $P$. eryngii used in this study are shown into Table 1 and Figure 1. All isolates investigated were stored as pure fungal cultures at $4^{\circ} \mathrm{C}$ on potato dextrose agar (PDA) media into the fungal culture collection of the mycology laboratory at University of Basilicata (UNIBAS), Potenza (Italy). The studied isolates were identified at species level by molecular methods using polymerase chain reaction (PCR) employing the primer pair ITS5/ITS4 (White et al., 1990), which amplify the internal transcribed spacer (ITS) 1 and 2 regions including the 5.8S rRNA gene of the ribosomal RNA. Genomic DNA isolation and PCR 
were performed as described by Mang and Figliuolo (2010). The obtained amplicons were directly sequenced by BMR S.r.1. Genomics Padova (Italy). The resulted sequences were analysed using the basic local alignment search tool (BLAST) (Altschul et $a l ., 1990)$ program and compared to the ITS nucleotide sequences already present in GenBank. The obtained sequences were deposited in the EMBL nucleotide database. Both, commercial and wild types of $P$. eryngii isolates were re-transferred to Petri dishes containing PDA and incubated at $22^{\circ} \mathrm{C}$ for 24 days. After incubation, the mycelium was suitable for the wooden sticks inoculation. Subsequently, twelve glass cylinders were prepared (one/isolate), containing 10 wooden sticks (well colonised by fungal mycelium) each and placed in an incubator at $22^{\circ} \mathrm{C}$ in dark. Packs of inoculated standard substrate, were prepared and put into cultivation in the horticulture laboratory of the UNIBAS. A total number of 72 substrate bags (6/isolate, $4.5 \mathrm{~kg}$ each) were used for inoculation with the wooden sticks. When the growth of the fungal mycelia became abundant and/or pinheads emerged, portions of the bags were cutoff to create perforations in order to facilitate the fruiting bodies development. Inoculated substrate bags were placed in a greenhouse at $25^{\circ} \mathrm{C} 5 \pm 2^{\circ} \mathrm{C}$ equipped with a black net overshadowing $(75 \%)$ on the roof. The cultivation of cardoncello took place following the technique described elsewhere by Rana et al. (2013). Relative humidity was maintained at $\approx 80 \%$ by spraying tap water. Experimental trials were monitored in order to observe the primordial formation and to evaluate the different growth rate of the $P$. eryngii isolates tested.

The cultivation started on October 10, 2016 (after a 4-day incubation of the substrate bag at $8^{\circ} \mathrm{C}$ ) and ended on November 24 , 2016. A total number of twelve experimental trials were carried out for the assay. We have applied a randomised block experimental design with three replicates, and each experimental unit included two substrate bags well colonised by mycelium. Basidioma harvest for all isolates was done in the first basidioma flush since it is generally the most consistent and usually corresponding to about 70$90 \%$ of the total production while the other flushes typically lead to less production $(\approx 10-30 \%)$. As stated by Ohga and Royse (2004), in general, the mushroom producers only harvest the $1^{\text {st }}$ flush of mushrooms.

\section{Biometric analysis}

For each P. eryngii isolate, experimental trial and repetition the biometric parameters were evaluated. Also, on a representative sample ( 5 basidioma/unit) the fresh weight was determined and the dry weight. Drying of the material was done in a ventilated stove at $60^{\circ} \mathrm{C}$ temperature, until the constant weight was reached. The following biometric parameters were assessed: i) production in the $1^{\text {st }}$ flush (days); ii) average harvest time in days; iii) percentage of large basidioma (with cap diameter $\geq 3 \mathrm{~cm}$ ); iv) basidioma medium weight (g); v) basidioma height (cm); vi) stem diameter (cm); vii) stem height $(\mathrm{cm})$; viii) cap diameter $(\mathrm{cm})$; ix) cap consistency $(\mathrm{kg}$ $\left.\mathrm{cm}^{-2}\right)$ and $\left.\mathrm{x}\right)$ dry matter (\%).

\section{Colorimetric analysis}

The colour of basidioma pileus cuticle was detected with a Minolta CR-400 electronic colorimeter (Minolta Corp., Osaka, Japan). Colour parameters were expressed as L* describing lightness $\left(L^{*}=0\right.$ for black, $L^{*}=100$ for white), $a^{*}$ describing intensity in green-red $\left(\mathrm{a}<0\right.$ for green, $\mathrm{a}>0$ for red), $\mathrm{b}^{*}$ describing intensity in blue-yellow ( $\mathrm{b}<0$ for blue, $\mathrm{b}>0$ for yellow) (Buckley and Giorgianni, 2016). Other colour components such as Chroma $\left(\mathrm{C}^{*}\right)$ and the Hue angle $\left(\mathrm{H}^{\circ}\right)$ were also calculated using specific math formulas (Castronuovo et al., 2015). Chroma measures colour saturation or intensity and the $\mathrm{H}^{\circ}$ describes the relative amounts of redness and yellowness where $0^{\circ} / 360^{\circ}$ is defined for red/magenta, $90^{\circ}$ for yellow, $180^{\circ}$ for green and $270^{\circ}$ for blue colour or purple (Konica Minolta, 2003).

\section{Statistical analysis}

All data were statistically analysed by ANOVA and mean values were separated by the Student-Newman-Keuls (SNK) test at $\mathrm{P} \leq 0.05$ using the SAS software (SAS Institute, Cary, NC, USA, 2015).

\section{Results and conclusions}

The PCR reaction performed with ITS5/ITS4 primers produced, in all isolates, a single amplicon of about $600 \mathrm{bp}$ in length permitting direct sequencing of the ITS region. The BLAST analysis of the obtained ITS nucleotide sequences in NCBI GenBank showed a $99 \%-100 \%$ similarity with the ITS sequences of $P$. eryngii already present in GenBank (MH854697; JQ837483 and FJ904728) confirming that all isolates studied belonged to P. eryngii. The $P$. eryngii ITS nucleotide sequences from this study were deposited in the EMBL nucleotide database under the accession numbers from LR633968 to LR633979 (Table 1).

The production, obtained for the $12 \mathrm{P}$. eryngii isolates analysed was highly variable, covering a wide range from $120 \mathrm{~g}$ ('Albino beige chiaro 1094') till 865.13 g ('Albino 1107') as shown in Table 2. The highest production of commercial isolates was obtained for 'V 160' (758.86 g) and '142 F' (739.69 g) and for the wild type isolates 'in Albino 1107' (865.13 g) and 'Conversano 1250 ' (863.96 g). Similar values were obtained in previous studies by Rana et al. (2013). The harvest earliness was very different among the commercial and wild type cardoncello isolates. The best values were registered for the wild type isolates 'Conversano 1250 ' (10.0 days) and 'Altamura 1603' (10.0 days) compared to commercial ' $142 \mathrm{E}$ ' isolate (17.32 days). Outcomes on harvest earliness from this study were different from those of previous studies on P. eryngii isolates performed by Rana et al. (2013) which reported no significant differences regarding the yield earliness

Table 1. Details on Pleurotus eryngii isolates used in this study.

\begin{tabular}{|c|c|c|}
\hline Isolate name & Type & $\begin{array}{c}\text { GenBank accession } \\
\text { number }\end{array}$ \\
\hline '142 F' & Commercial & LR633968 \\
\hline '142 E' & $\therefore$ & LR633969 \\
\hline 'D+' & $\therefore$ & LR633970 \\
\hline 'V turbo' & $\therefore$ & LR633971 \\
\hline 'V 142' & $\therefore$ & LR633972 \\
\hline 'A 12' & $\therefore$ & LR633973 \\
\hline 'V 160' & $\therefore$ & LR633974 \\
\hline 'Albino beige chiaro 1094' & Wild & LR633975 \\
\hline 'Altamura 1603' & $\therefore$ & LR633976 \\
\hline 'Albino 1107' & $\therefore$ & LR633977 \\
\hline 'Muro Lucano 139' & $\therefore$ & LR633978 \\
\hline 'Conversano 1250' & $\therefore$ & LR633979 \\
\hline
\end{tabular}


among all tested isolates.

The highest percentage of large basidioma was observed for the commercial isolates 'V turbo' (96.29\%), 'D +' (95.76\%) and ' 142 E' (93.44\%) while the lowest values were seen in the wild type isolates 'Muro Lucano 139' (29.08\%) and 'Albino 1107' (31.48\%). The average weight of basidioma exceeded $60 \mathrm{~g}$ for the commercial isolates ' $142 \mathrm{~F}$ ' and ' $\mathrm{V}$ 160', while another commercial isolate 'A 12' isolate produced basidioma of smaller size (27 $\mathrm{g}$ ); in all other commercial isolates the weight of the basidioma ranged from $53 \mathrm{~g}$ for ' $\mathrm{V}$ turbo' to $41.2 \mathrm{~g}$ for ' $\mathrm{V} 142$ '. Besdides, the wild type isolates 'Altamura 1603' (42.5 g) and 'Conversano 1250' $(40.5 \mathrm{~g})$ had the highest average weight of the basidioma while the 'Albino 1107' (17.3 g) wild type had the lowest one (Table 3).

Commercial isolates ' $142 \mathrm{E}$ ' $(8.78 \mathrm{~cm})$ and ' $\mathrm{D}+$ ' $(8.74 \mathrm{~cm})$ distinguished themselves by the greater diameter of the stem along with ' $142 \mathrm{~F}$ ' $(8.52 \mathrm{~cm})$. The smallest values were registered for the wild type isolates 'Albino beige chiaro 1094' and 'Albino 1107' both having a stem diameter of $4.13 \mathrm{~cm}$. The highest height cap values was registered for the 'Muro Lucano 139' wild type isolate $(9.79 \mathrm{~cm})$ closely followed by the commercial isolate ' $142 \mathrm{E}$ ' (9.29 $\mathrm{cm}$ ) while the lowest values for the cap height was registered for the 'A 12' commercial isolate $(6.23 \mathrm{~cm})$. The maximum values for the stem height were registered for the wild type $P$. eryngii isolates 'Albino 1107' (5.59 cm) and 'Muro Lucano 139' (5.01 cm) followed by the commercial ' $142 \mathrm{~F}$ ' isolate $(4.86 \mathrm{~cm})$. On the opposite, the lowest values for the stem height was registered for the 'A $12^{\prime}(2.87 \mathrm{~cm})$ commercial isolate.

The 'A 12' isolate was characterised by the almost rounded basidioma shape, having reached the largest diameter of the cap $(3.12 \mathrm{~cm})$ while 'Albino 1107 ' isolate showed the smallest diameter of the cap $(1.37 \mathrm{~cm})$. The commercial cardoncello isolates ' $\mathrm{V}$ 160 ', 'V turbo' and '142 E' had almost equal values for the cap diameter ranging from 2.68 to $2.79 \mathrm{~cm}$ (Table 3).

The trend of the cap consistency among all isolates analysed was very different and varied from a minimum of $1.1 \mathrm{~kg} \mathrm{~cm}^{-2}$ for ' $\mathrm{D}+$ ' commercial isolate up to a maximum of $4.1 \mathrm{~kg} \mathrm{~cm}^{-2}$ for the 'Albino beige chiaro 1094' wild type isolate.
Regarding the dry matter content, the highest percentage was registered in the wild type isolates 'Albino beige chiaro 1094' (24.33\%) and 'Muro Lucano 139' (22.65\%) and the lowest in two wild type isolates 'Altamura 1603' (10.04\%) and 'Conversano 1250 ' $(8.97 \%)$, compared to all others that, on average, reached $12.7 \%$ (Table 3 ).

The $\mathrm{L}^{*}$ value ranged between 87.43 to 45.97 , while a-values (red/green) and b-values (yellow/blue) ranged between 1.87-7.24 and 15.2-24.04, respectively according to Wan-Rosli (2013). The $\mathrm{L}^{*}$ values of commercial type $P$. eryngi isolates were lower than wild type isolates, thus more dark and attractive from consumers, in particular 'V turbo' (45.97) and 'V 160' (46.21) compared to

Table 2. Productivity and harvest earliness parameters of P. eryngii commercial and wild type isolates.

\begin{tabular}{lcc} 
Isolate name & \multicolumn{2}{c}{ Parameters* } \\
& Production [1 st flush] (g) $^{\text {AHI }}{ }^{\circ}$ (days) \\
'142 F' & $739.69^{\mathrm{ab}}$ & $20.09^{\mathrm{bc}}$ \\
'142 E' & $610.48^{\mathrm{ac}}$ & $17.32^{\mathrm{c}}$ \\
\hline 'D+' & $421.75^{\mathrm{bc}}$ & $22.03^{\mathrm{b}}$ \\
'V turbo' & $589.44^{\mathrm{ac}}$ & $23.08^{\mathrm{b}}$ \\
\hline 'V 142' & $479.17^{\mathrm{bc}}$ & $21.15^{\mathrm{bc}}$ \\
'A 12' & $239.19^{\mathrm{de}}$ & $27.52^{\mathrm{a}}$ \\
\hline 'V 160' & $758.86^{\mathrm{ab}}$ & $17.66^{\mathrm{c}}$ \\
'Albino 1107' & $865.13^{\mathrm{a}}$ & $12.00^{\mathrm{d}}$ \\
\hline 'Altamura 1603' & $723.03^{\mathrm{ab}}$ & $10.00^{\mathrm{d}}$ \\
'Muro Lucano 139' & $186.87^{\mathrm{e}}$ & $17.00^{\mathrm{c}}$ \\
\hline 'Conversano1250' & $863.9^{\mathrm{a}}$ & $10.00^{\mathrm{d}}$ \\
'Albino beige chiaro 1094' & $115.17^{\mathrm{e}}$ & $11.00^{\mathrm{d}}$ \\
\hline
\end{tabular}

*Values with different superscript are significantly different at $\mathrm{P} \leq 0.05$ according to the $\mathrm{SNK}$ test; ${ }^{\circ} \mathrm{AHT}$ (average harvest time, days $)=\left(w_{1} . d_{1}\right) \ldots \ldots \ldots . . .\left(w_{n} . d_{n}\right) / P$. Where: $d=$ time (days) from the culture initiation; $\mathrm{W}=$ basidioma weight (marketable production) of each harvest ('flush'); $\mathrm{P}=$ production.

Table 3. Morphological and qualitative parameters of P. eryngii commercial and wild type isolates.

\begin{tabular}{|c|c|c|c|c|c|c|c|c|}
\hline Isolate name & $\begin{array}{c}\text { Large basidioma } \\
(\%)\end{array}$ & $\begin{array}{l}\text { Medium weight } \\
\text { (g) }\end{array}$ & $\begin{array}{c}\text { Basidioma } \\
\text { Height } \\
\text { (cm) }\end{array}$ & $\begin{array}{l}\text { Parameter } \\
\text { Diameter } \\
\text { (cm) }\end{array}$ & $\begin{array}{l}\text { Height } \\
\text { (cm) }\end{array}$ & $\begin{array}{c}\text { Stem Cap } \\
\text { Diameter } \\
(\mathrm{cm})\end{array}$ & $\begin{array}{c}\text { Consistency } \\
\left(\mathrm{kg} \mathrm{cm}^{-2}\right)\end{array}$ & $\begin{array}{c}\text { Dry matter } \\
(\%)\end{array}$ \\
\hline '142 F' & $90.78^{\mathrm{ab}}$ & $64.89^{\mathrm{a}}$ & $8.34^{\mathrm{abc}}$ & $8.52^{\mathrm{ab}}$ & $4.86^{\mathrm{ac}}$ & $2.41^{\mathrm{ac}}$ & $1.85^{\mathrm{bd}}$ & $11.91^{\mathrm{bc}}$ \\
\hline '142 E' & $93.44^{\mathrm{a}}$ & $47.89^{\mathrm{bc}}$ & $9.29^{a b}$ & $8.78^{a}$ & $4.73^{\mathrm{ac}}$ & $2.68^{\mathrm{ab}}$ & $1.61^{\mathrm{bd}}$ & $12.38^{\mathrm{bc}}$ \\
\hline$' \mathrm{D}+{ }^{\prime}$ & $95.76^{\mathrm{a}}$ & $41.60^{\text {cd }}$ & $7.67^{\mathrm{ac}}$ & $8.74^{\mathrm{a}}$ & $3.46^{\mathrm{de}}$ & $2.00^{\mathrm{bc}}$ & $1.11^{\mathrm{d}}$ & $10.06^{\mathrm{cd}}$ \\
\hline 'V turbo' & $96.29^{\mathrm{a}}$ & $52.98^{\mathrm{ac}}$ & $7.68^{a c}$ & $7.41^{\text {ac }}$ & $3.79^{c e}$ & $2.70^{\mathrm{ab}}$ & $2.16^{\mathrm{bc}}$ & $12.25^{\mathrm{bc}}$ \\
\hline 'V 142' & $86.09^{\mathrm{ab}}$ & $41.23^{\mathrm{cd}}$ & $6.86^{\mathrm{bc}}$ & $7.58^{\mathrm{ac}}$ & $2.99 \mathrm{e}$ & $2.10^{\mathrm{ac}}$ & $1.58^{\mathrm{bd}}$ & $13.04^{b}$ \\
\hline 'A 12' & $86.78^{\mathrm{ab}}$ & $27.19^{\text {de }}$ & $6.23^{\mathrm{c}}$ & $6.54^{\text {cd }}$ & $2.87^{\mathrm{e}}$ & $3.12^{\mathrm{a}}$ & $1.29^{\text {cd }}$ & $13.44^{b}$ \\
\hline 'V 160’ & $78.76^{\mathrm{ab}}$ & $60.23^{\mathrm{ab}}$ & $8.11^{\mathrm{ac}}$ & $7.06^{\mathrm{bc}}$ & $4.31^{\mathrm{bd}}$ & $2.79^{\mathrm{ab}}$ & $2.38^{b}$ & $13.08^{b}$ \\
\hline 'Albino 1107' & $31.48^{d}$ & $17.34^{\mathrm{e}}$ & $7.84^{\mathrm{ac}}$ & $4.13^{\mathrm{e}}$ & $5.59^{\mathrm{a}}$ & $1.37^{\mathrm{c}}$ & $1.89^{\mathrm{bd}}$ & $13.75^{b}$ \\
\hline 'Altamura 1603' & $51.06^{\mathrm{c}}$ & $42.52^{\mathrm{cd}}$ & $6.62^{b c}$ & $7.00^{\mathrm{bc}}$ & $3.43^{\mathrm{de}}$ & $2.00^{\mathrm{bc}}$ & $1.70^{\mathrm{bd}}$ & $10.04^{\mathrm{cd}}$ \\
\hline 'Muro Lucano 139' & $29.08^{d}$ & $29.63^{\mathrm{de}}$ & $9.79^{\mathrm{a}}$ & $5.20^{\mathrm{de}}$ & $5.01^{\mathrm{ab}}$ & $2.42^{\mathrm{ac}}$ & $2.42^{b}$ & $22.65^{\mathrm{a}}$ \\
\hline 'Conversano 1250' & $72.60^{\mathrm{b}}$ & $40.54^{\text {cd }}$ & $7.20^{\mathrm{ac}}$ & $7.15^{\mathrm{ac}}$ & $3.78^{\mathrm{ce}}$ & $1.85^{\mathrm{bc}}$ & $1.39^{\text {cd }}$ & $8.97^{\mathrm{d}}$ \\
\hline 'Albino beige chiaro & $1094^{\prime} \quad 46.74^{c}$ & $20.22^{\mathrm{e}}$ & $6.55^{\mathrm{bc}}$ & $4.13^{\mathrm{e}}$ & $4.28^{\mathrm{bd}}$ & $1.79^{\mathrm{bc}}$ & $4.12^{\mathrm{a}}$ & $24.33^{\mathrm{a}}$ \\
\hline
\end{tabular}

*Values with different superscript are significantly different at $\mathrm{P} \leq 0.05$ according to the SNK test; ${ }^{\circ}$ large basidioma $=$ basidioma with diameter $\geq 3 \mathrm{~cm}$. ${ }^{*}$ Values with different superscript are significantly different at $\mathrm{P} \leq 0.05$ according to the SNK test; ${ }^{\circ}$ large basidioma $=$ basidioma with diameter $\geq 3 \mathrm{~cm}$. 
'Albino 1107' (87.43). The Hue angle range was between $0^{\circ}$ the $90^{\circ}$ region which suggests a red-yellow colour (Table 4 ).

This study showed that great differences were recorded among all $P$. eryngii tested isolates regarding parameters analysed similarly to what stated previously by other authors (De Gioia et al., 2007;
Rana et al., 2013). Since important features as productivity and harvest earliness were very good in some of the wild type P. eryngii isolates e.g. 'Conversano 1250' and 'Albino 1107' certainly, more investigations on this particular isolates should be planned.

Further investigations are needed to verify the importance of
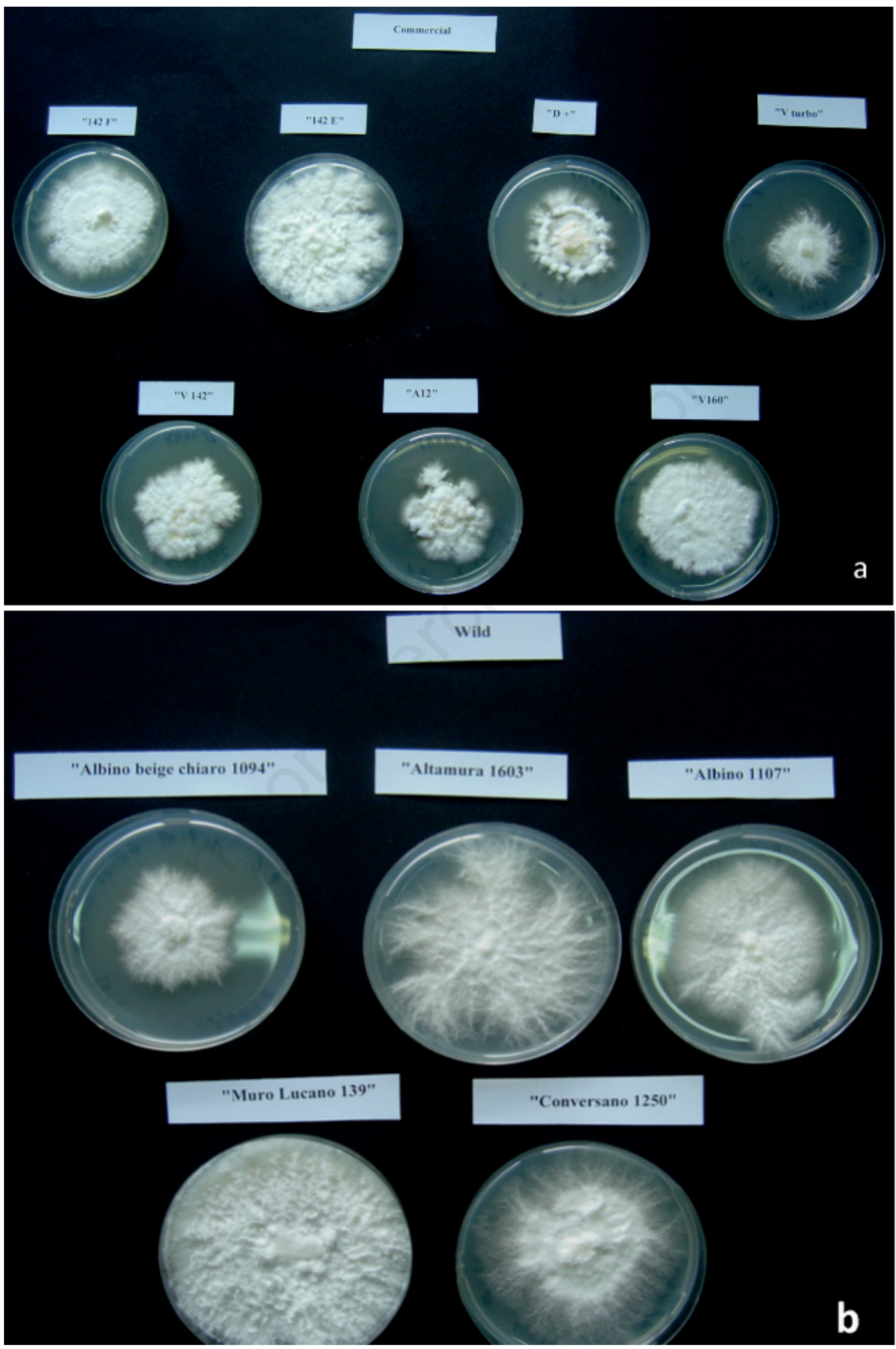

Figure 1. Aspect of the colonies (in different age) of $P$. eryngii isolates commercial (A) and wild type (B) investigated. 
Table 4. Pileus colorimetric characterisation of commercial and wild type P. eryngii isolates.

\begin{tabular}{|c|c|c|c|c|c|c|}
\hline \multirow[t]{2}{*}{ Isolates } & \multicolumn{6}{|c|}{ Colorimetric parameters $^{\circ}$} \\
\hline & $L^{*}$ & $a^{*}$ & b* & $a * / b^{*}$ & $C^{*}$ & H \\
\hline '142 F' & $52.26^{\mathrm{df}}$ & $6.36^{\mathrm{b}}$ & $17.14^{\mathrm{ce}}$ & $0.37^{\mathrm{ab}}$ & $18.28^{\mathrm{ce}}$ & $69.64^{\mathrm{ef}}$ \\
\hline '142 E' & $50.68^{\mathrm{ef}}$ & $7.24^{\mathrm{a}}$ & $19.35^{\mathrm{bc}}$ & $0.37^{\mathrm{ab}}$ & $20.67^{\mathrm{bc}}$ & $69.44 \mathrm{ef}^{\mathrm{f}}$ \\
\hline 'D+' & $59.75^{\mathrm{cd}}$ & $5.85^{b}$ & $18.11^{\mathrm{bd}}$ & $0.32^{b c}$ & $19.04^{\text {be }}$ & $72.04^{\mathrm{de}}$ \\
\hline 'V turbo' & $45.97^{\mathrm{f}}$ & $5.95^{\mathrm{b}}$ & $15.25^{\mathrm{e}}$ & $0.39^{\mathrm{a}}$ & $16.37 \mathrm{e}$ & $68.63^{f}$ \\
\hline 'V 142' & $55.36^{\text {ce }}$ & $6.12^{\mathrm{b}}$ & $17.46^{\mathrm{ce}}$ & $0.35^{\mathrm{ac}}$ & 18.49ce & $70.69^{\mathrm{df}}$ \\
\hline 'A 12' & $54.33^{\mathrm{ce}}$ & $6.63^{\mathrm{ab}}$ & $18.62^{\mathrm{bd}}$ & $0.35^{\mathrm{ac}}$ & $19.77^{\text {bd }}$ & $70.42^{\mathrm{df}}$ \\
\hline 'V 160' & $46.21^{\mathrm{f}}$ & $6.35^{b}$ & $16.11^{\mathrm{de}}$ & $0.39^{a}$ & $17.31^{\mathrm{de}}$ & $68.50^{\mathrm{f}}$ \\
\hline 'Albino 1107' & $87.43^{\mathrm{a}}$ & $1.87^{\mathrm{e}}$ & $24.04^{\mathrm{a}}$ & $0.08^{f}$ & $24.13^{\mathrm{a}}$ & $85.63^{\mathrm{a}}$ \\
\hline 'Altamura 1603' & $57.42^{\mathrm{ce}}$ & $6.33^{b}$ & $20.66^{\mathrm{b}}$ & $0.31^{\mathrm{c}}$ & $21.62^{b}$ & $72.97^{\mathrm{d}}$ \\
\hline 'Muro Lucano 139' & $61.09^{c}$ & $4.93^{c}$ & $19.22^{\mathrm{bc}}$ & $0.26^{\mathrm{d}}$ & $19.84^{\text {bd }}$ & $75.63^{c}$ \\
\hline 'Conversano 1250' & $62.04^{c}$ & $6.02^{\mathrm{b}}$ & $19.54^{\mathrm{bc}}$ & $0.31^{\mathrm{c}}$ & $20.45^{\mathrm{bc}}$ & $72.91^{\mathrm{d}}$ \\
\hline 'Albino beige chiaro 1094' & $72.40^{\mathrm{b}}$ & $2.98^{\mathrm{d}}$ & $19.33^{b c}$ & $0.15^{\mathrm{e}}$ & $19.56^{\text {bd }}$ & $81.26^{\mathrm{b}}$ \\
\hline
\end{tabular}

${ }^{\circ}$ Values with different superscript are significantly different at $\mathrm{P} \leq 0.05$ according to the $\mathrm{SNK}$ test. Colour indexes: $\mathrm{L}^{*}=$ luminosity index; $\mathrm{a}^{*}=$ red-green component index; $\mathrm{b}^{*}=$ yellow-blue component index; $\mathrm{C}^{*}=$ saturation index (chroma): $\mathrm{H}=$ colour tone 'Hue'.

the $P$. eryngii colour in consumer preferences. In fact, only few studies (Martínez-Soto et al., 2001; Nour et al., 2011) were found where colour in dried mushrooms had been linked to consumer preference but this hypothesis was not supported by experimental evidence.

Further investigations are needed to better generalise the results from this study. It will be necessary to take into account a greater number of isolates, especially wild type ones, and to test them in a larger variety of growth conditions. Another possible direction is to explore the biodiversity of $P$. eryngii, discovering new fungal isolates.

\section{References}

Altschul SF, Gish W, Miller W, Myers EW, Lipman JD, 1990. Basic local alignment search tool. J. Molec. Biol. 215:403-10.

Camele I, Altieri L, Rana GL, 2010. Prima segnalazione di due basidiomiceti contaminanti il substrato di coltivazione di Pleurotus eryngii. Micol. Ital. 3:14-9.

Chang ST, 1996. Mushroom research and development-equality and mutual benefit. In: Mushroom biology and mushroom products. pp 1-10 in Proceeding of the Second International Conference on Mushroom Biology and Mushroom Products. Royse D.J. (ed.), Pennsylvania State University, PA, USA.

Coli R, Granetti B, Damiani P, Fidanza F, 1988. Composizione chimica e valore nutritivo di alcuni ceppi di Pleurotus eryngii, P. nebrodensis e P. ostreatus coltivati serra. Ann. Fac. Agr. Perugia 42:84-7859.

De Gioia T, Figliuolo G, Rana GL, Sisto D, 2007. Confronto morfoproduttivo tra alcuni ceppi selvatici e commerciali di Pleurotus eryngii (D.C.: Fr.) Quél. in coltura protetta. Micol. Ital. 36:35-46.

Ferri F, 1986. I funghi - Micologia, isolamento, coltivazione. Ed. Edagricole, Bologna, Italy.

Ferri F, 2000. Problematiche nella coltivazione climatizzata del cardoncello (Pleurotus eryngii). Agric. Ric. 188:47-52.

Ferri F, Zjalic S, Reverberi M, Fabbri AA, Fanelli C, 2007. I funghi Coltivazione e proprietà medicinali. Ed. Edagricole, Bologna, Italy.
Gorai B, Sharma R, 2018. Determination of optimum Temperature and $\mathrm{pH}$ for mycelial growth of Pleurotus spp./strains. Int. J. Microbiol. Res. 10:1287-9.

Gunde-Cimerman N, 1999. Medicinal value of the genus Pleurotus (Fr.) P. Karst. (Agaricales s.l., Basidiomycetes). Int. J. Med. Mushrooms 1:69-80.

Guzmàn G, 2000. Genus Pleurotus (Jacq.: Fr) P. Kumm. (Agaricomycetideae): diversity, taxonomic problems, and cultural and traditional medicinal uses. Int. J. Med. Mushrooms 2:95-123.

Hobbs C (ed.), 1995. Medicinal mushrooms: an exploration of tradition, healing and culture. Botanica Press, Santa Cruz, CA, USA.

Jong SC, Donovich R, 1989. Antitumor and antiviral substances from fungi. Adv. Appl. Microbiol. 34:183-261.

Kim M, Ryu J, Lee Y, Kim H, 2013. Breeding of a long shelf-life isolate for commercial cultivation by mono-mono crossing in Pleurotus eryngii. Sci. Hort. 162:265-70.

Maddau L, Franceschini A, Serra S, Marras F, 2000. Nuove acquisizioni sulla coltivazione del cardoncello (Pleutorus eryngii). Agric. Ric. 188:41-6.

Mang SM, Figliuolo G, 2010. Species delimitation in Pleurotus eryngii species-complex inferred from ITS and EF-1 gene sequences. Mycology 1:269-80.

Manzi P, Gambelli L, Marconi S, Vivanti V, Pizzoferrato L, 1999. Nutrients in edible mushroons: an inter-species comparative study. Food Chem. 65:477-82.

Muszyńska B, Kała K, Sułkowska-Ziaja K, 2017. Edible mushrooms and their in vitro culture as a source of anticancer compounds. In: S. Malik (ed.), Biotechnology and Production of Anti-Cancer Compounds, Springer International Publishing AG, Berlin, Germany, pp. 231-251.

Ngai PHK, Ng TB, 2006. A hemolysin from the mushroom Pleurotus eryngii. Appl. Microbiol. Biotechnol. 72:1185-91.

Nour V, Trandafir I, Ionica ME, 2011. Effects of pre-treatments and drying temperatures on the quality of dried button mushrooms. South West. J. Hortic. Biol. Environ. 2:15-24.

Ohga S, Royse DJ, 2004. Cultivation of Pleurotus eryngii on umbrella plant (Cyperus alternifolius) substrate. J. Wood Sci. 50:466-9.

Rana GL, Sisto D, Mang SM, Candido V, 2013. Preliminary stud- 
ies on productivity of white Pleurotus eryngii isolates in protected cultivation. Ital. J. Agr. 8:41-6.

Rodrigues-Estrada EA, Gasco-Jimenez M del M, Royse JD, 2010. Pleurotus eryngii species complex: sequence analysis and phylogeny based on partial EF1 and RPB2 genes. Fungal Biol. 114:421-8.

Ryu J, Kim M, Im C, Shin P, 2015. Development of cultivation media for extending the shelf-life and improving yield of king oyster mushrooms (Pleurotus eryngii). Sci. Hort. 193:121-6.

SAS Institute Inc. 2015. SAS Visual Analytics 7.2: User's Guide. SAS Institute Inc., Cary, NC, USA.

Sisto D, Faggiano S, Mannerucci F, 1998. Nuovi substrati per la coltivazione del cardoncello. Agr. Ric. 176:47-50.

Martínez-Soto G, Ocanña-Camacho R, Paredes-López O, 2001. Effect of pretreatment and drying on the quality of oyster mushrooms (Pleurotus ostreatus). Drying Technol. 19:661-72.

Venturella G, Palazzolo E, Saiano F, Gargano M, 2015. Notes on a new productive isolate of king oyster mushroom, Pleurotus eryngii (Higher Basidiomycetes), a prized Italian culinarymedicinal mushroom. Int. J. Med. Mushrooms 17:199-206.

Wan-Rosli WI, Aishah MS, 2013. Effect of different drying techniques on the nutritional values of oyster mushroom (Pleurotus sajor-caju). Sains Malaysiana 42:937-41.

Wang H, Ng T, 2001. Pleureryn, a novel protease from fresch fruiting bodies of the edible mushroom Pleurotus eryngii. Biochem. Biophys. Res. Commun. 289:750-5.

White TJ, Bruns T, Lee J, Taylor J, 1990. Amplification and direct sequencing of fungal ribosomal RNA genes for phylogenetics. In: Innis MA, White TJ, Sninsky JJ and Gelfand DH (eds). PCR Protocols: A Guide to Methods and Applications. Academic Press Inc., New York, NY, USA, pp. 315-22.

Zervakis G, Balis CA, 1996. Pluralistic approach in the study of Pleurotus species with emphasis on compatibility and physiology of the European morphotaxa. Mycol. Res. 100:717-31.

Zervakis GI, Ntougias S, Gargano ML, Besi MI, Polemis E, Typas MA, Venturella G , 2014. A reappraisal of the Pleurotus eryngii complex-New species and taxonomic combinations based on the application of a polyphasic approach, and an identification key to Pleurotus taxa associated with Apiaceae plants. Fungal Biol. 118:814-34.

Zhang R, Hu D, Ma X, Li S, Gu J, Hu Q, 2014. Adopting stick spawn reduced the spawn running time and improved mushroom yield and biological efficiency of Pleurotus eryngii. Sci. Hort. 175:156-9. 